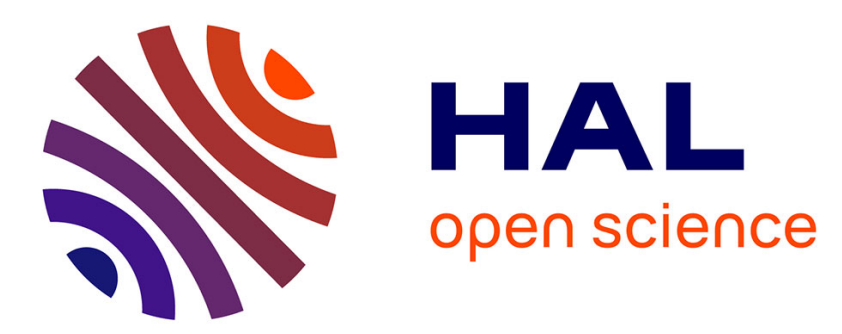

\title{
Three-dimensional analysis of load transfer micro-mechanisms in fibre/matrix composites
}

Sébastien Blassiau, Alain Thionnet, Anthony R. Bunsell

\section{To cite this version:}

Sébastien Blassiau, Alain Thionnet, Anthony R. Bunsell. Three-dimensional analysis of load transfer micro-mechanisms in fibre/matrix composites. Composites Science and Technology, 2009, 69, pp.3339. 10.1016/j.compscitech.2007.10.041 . hal-00350433

\section{HAL Id: hal-00350433 https://hal.science/hal-00350433}

Submitted on 25 Jan 2016

HAL is a multi-disciplinary open access archive for the deposit and dissemination of scientific research documents, whether they are published or not. The documents may come from teaching and research institutions in France or abroad, or from public or private research centers.
L'archive ouverte pluridisciplinaire HAL, est destinée au dépôt et à la diffusion de documents scientifiques de niveau recherche, publiés ou non, émanant des établissements d'enseignement et de recherche français ou étrangers, des laboratoires publics ou privés. 


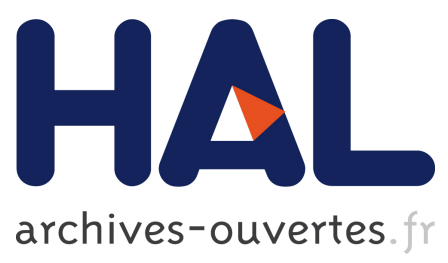

\section{Three-dimensional analysis of load transfer micro-mechanisms in fibre/matrix composites}

S. Blassiau, A. Thionnet, Anthony R. Bunsell

\section{To cite this version:}

S. Blassiau, A. Thionnet, Anthony R. Bunsell. Three-dimensional analysis of load transfer micro-mechanisms in fibre/matrix composites. Composites Science and Technology, Elsevier, 2009, 69 (1), pp.33. <10.1016/j.compscitech.2007.10.041>. <hal-00563493>

\section{HAL Id: hal-00563493 \\ https://hal.archives-ouvertes.fr/hal-00563493}

Submitted on 6 Feb 2011

HAL is a multi-disciplinary open access archive for the deposit and dissemination of scientific research documents, whether they are published or not. The documents may come from teaching and research institutions in France or abroad, or from public or private research centers.
L'archive ouverte pluridisciplinaire $\mathbf{H A L}$, est destinée au dépôt et à la diffusion de documents scientifiques de niveau recherche, publiés ou non, émanant des établissements d'enseignement et de recherche français ou étrangers, des laboratoires publics ou privés. 


\section{Accepted Manuscript}

Three-dimensional analysis of load transfer micro-mechanisms in fibre/matrix composites

S. Blassiau, A. Thionnet, A.R. Bunsell

PII: S0266-3538(07)00438-1

DOI: 10.1016/j.compscitech.2007.10.041

Reference:

CSTE 3887

To appear in:

Composites Science and Technology

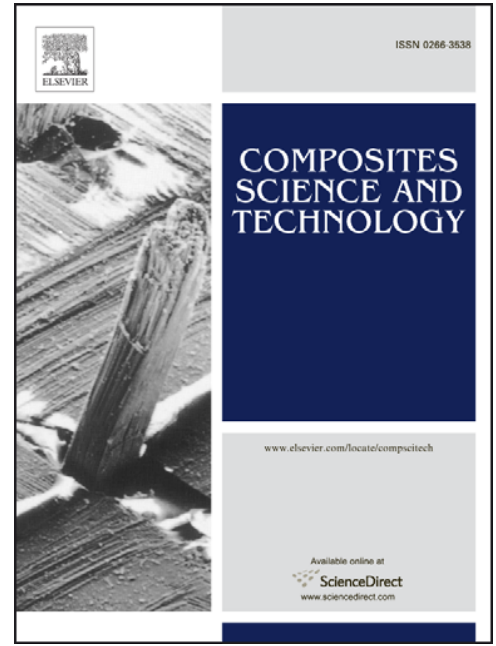

Received Date: $\quad 14$ May 2007

Accepted Date: $\quad 11$ October 2007

Please cite this article as: Blassiau, S., Thionnet, A., Bunsell, A.R., Three-dimensional analysis of load transfer micro-mechanisms in fibre/matrix composites, Composites Science and Technology (2007), doi: 10.1016/ j.compscitech.2007.10.041

This is a PDF file of an unedited manuscript that has been accepted for publication. As a service to our customers we are providing this early version of the manuscript. The manuscript will undergo copyediting, typesetting, and review of the resulting proof before it is published in its final form. Please note that during the production process errors may be discovered which could affect the content, and all legal disclaimers that apply to the journal pertain. 


\title{
ACCEPTED MANUSCRIPT
}

\section{THREE-DIMENSIONAL ANALYSIS OF LOAD TRANSFER MICRO- MECHANISMS IN FIBRE/MATRIX COMPOSITES}

\author{
S. Blassiau*,**, A. Thionnet*,***, A.R. Bunsell* \\ *Ecole des Mines de Paris, Centre des Matériaux, BP 8791003 Evry Cedex, France \\ **Gaz de France, Direction de la Recherche, 361, avenue du Président Wilson B.P. 3393211 \\ Saint-Denis La Plaine cedex, France \\ ***Université de Bourgogne - BP 47870 - 21078 Dijon - France
}

\begin{abstract}
This study gives a detailed analysis of load distributions around fibre breaks in a composite. In contrast to other studies reported in the literature, the analysis considers different configurations of composite damage from the failure of a few to the failure of many fibres. The model considers three types of matrix behaviours (elastic, elastic-plastic and viscoelastic) with or without debonding at the broken fibre/matrix interface. In this way, the usual limitations of the finite element approach are overcome so as to take into account the number and interactions of broken fibres whilst maintaining an evaluation of the various fields (stresses in particular).
\end{abstract}

Keywords : Fibre matrix interaction, Finite element modelling, Load transfer, Unidirectional composites, Debonding, Damage accumulation. 


\section{ACCEPTED MANUSCRIPT}

\section{INTRODUCTION}

Many studies have considered the effects of the loads transferred between broken fibres and the surrounding matrix and neighbouring intact fibres, in composite materials (Cox, Hedgepeth et al., Landis et al.). The increased stresses in the regions around the broken fibres determine the probability of further composite damage being accumulated and ultimately failure occurring. Many of the models which have considered this problem have been analytical, starting with the work of Cox who considered a short elastic fibre enveloped in a more deformable elastic matrix. This original model was two dimensional but others have extended the concepts to the $3 \mathrm{D}$ case but have not been able to give a satisfactory description of the stresses transferred to intact fibres neighbouring a broken fibre. Three dimensional finite element (F.E.)models, of which there are few, have, however, revealed that by such an approach the loads transferred to the intact regions around broken fibres can be explored (Wisnom et al., Heuvel et al.). The F.E. approach offers the possibility of modelling, with precision, the details of the composite microstructure in a way that is not feasible by an analytical approach.

The present study uses multi-scale 3D F.E. modelling, which at it finest level distinguishes the fibres and the matrix and is able to explore the effects of fibre-matrix debonding as well as elastic, plastic and viscoelastic behaviour of the matrix on composite damage accumulation. The study differs from others as it considers several microstructures with varying degrees of damage accumulation. This is possible through the use of a "representative elementary volume" or R.E.V. which is considered to be made up of a regular network of elementary cells and can be characteristic of all the damage states. The significance of the initial debonding of the fibre-matrix interface on load transfer is particularly important in understanding damage accumulation. 


\section{Modelling Fibre Failure}

The finest level of the model considers damage accumulation within the R.E.V. and takes into account the different roles of the fibres and the matrix. The literature shows that the perturbations in the stress field produced by the failure of a fibre are restricted to its immediate surroundings. The surrounding intact fibres screen the effects and beyond the third nearest intact fibre neighbouring the break the effect is negligible on the stress state of the material. For this reason, five R.E.V.s representing different damage states in the composite have been considered, as follows :

- E-2 represents one broken fibre in two

- E-4 represents one broken fibre in four

- E-8 represents one broken fibre in eight

- E-16 represents one broken fibre in sixteen

- E- $\infty$ represents only one broken fibre in the composite

The E-2 damage state is the most extreme condition and would result in the failure of the associated R.E.V. The E-16 state represents the situation in which there is no interaction between sites of failure in the composite. The different damage configurations considered are shown by the five cells in Figure 1.

The C- $\infty$ cell represents the state modelled by Nedele et Wisnom (Wisnom et al.) who considered two fibres surrounded by a continuum having the homogenised properties of the composite. This is the self consistent model and will be used as a reference so as to validate the present model. 


\section{ACCEPTED MANUSCRIPT}

In the present model three distinct behaviours of the matrix have been considered and the relevant coefficients are shown in Table 1, in which $\mathrm{E}$ are the tensile moduli, $v$ Poisson's ratios and $\tau$ time constants. $\mathrm{C}$ and $\mathrm{R}_{0}$ are characteristics considered for the elastic-plastic model and will be described below.

The first and simplest behaviour considers the matrix to be linearly elastic and homogeneously isotropic. The second considers the matrix to behave as a viscous medium. For this study a linear viscoelastic model has been used which corresponds to a unidirectional Zener solid, obeying the following expression;

$$
\dot{\sigma}+\gamma \sigma=C_{0} \dot{\varepsilon}+\gamma C_{\infty} \mathcal{E}
$$

The third behaviour considered, elasto-plastic behaviour, can be seen as the limiting case in the viscoelastic model for which the relaxation tensors are large. The elasto-plastic model due to Prager is used which considers linear dynamic work hardening of the matrix, for which $\mathrm{C}$ is the work hardened modulus and $\mathrm{R}_{0}$ the yield point.

\section{Calculated Parameters}

The aim of this present model is to be able to calculate the effects of the failure of a fibre on the stresses in neighbouring intact fibres as a function of time, taking into account the distance along the fibres from the plane of fibre failure and the extent of any debonding which occurs. A load transfer coefficient, $k_{r}$, is calculated at points along the fibres from the plane of failure and defined as the mean of values between two consecutive F.E. meshes divided by the value without fibre failure. This gives 
$k_{r}(t, Z)=\frac{\int_{z_{i}}^{z_{i+1}} \sigma_{z z}(t, z) d z}{\int_{z_{i}}^{z_{i+1}} \sigma_{z z}^{0}(t, z) d z}$, with $Z=\frac{\left(z_{i+1}+z_{i}\right)}{2} \ldots \ldots \ldots \ldots .2$

$\mathrm{t}$ is the time after fibre failure;

$\mathrm{Z}$ is the point along the fibre taken from the plane of fibre failure $\left(\mathrm{z}_{0}=0\right)$;

$\sigma_{z z}$ is the axial stress in the fibre;

$\sigma_{z z}^{0}$ is the axial stress in the fibre without a break;

$z_{i+1}, z_{i}$ are the neighbouring sections along the fibre between which the mean values are calculated.

The effects of time are only relevant in the case of viscoelastic behaviour of the matrix.

The definition of $k_{r}$ remains valid irrespective of whether the fibre/matrix interface debonds or not. However, so as to distinguish between the two states we define;

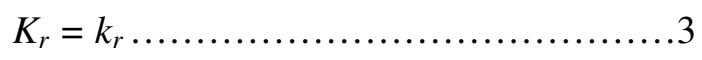

in the case where debonding does not occur

and

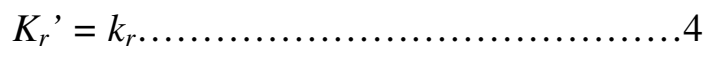

in the case where debonding does occur.

In the latter case we can write; 


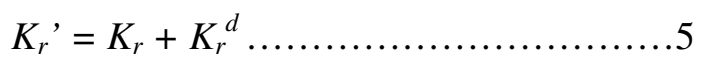

in which $K_{r}^{d}$ describes the stress concentration over the bonded length from the point at which the interface remains intact.

The above coefficients have been calculated for the following situations:

Configuration 1: $\mathrm{C}-\infty$ in which all the constituents are taken to be elastic and homogeneously isotropic and the debonded length is increased from zero.

Configuration 2: the same conditions for the composites as in configuration 1 but considered for the various states of damage which have been defined.

Configuration 3: the two previous states are now reconsidered with a linearly viscoelastic homogeneous and isotropic matrix. The fibre volume fraction considered has been $40 \%$ for all cells so as to better reveal the effects of the viscosity on the load transfer.

Configuration 4: similar to configuration 2 but for an elasto-plastic matrix so as to investigate the effects of loading and unloading the composite on the load transfer coefficient.

\section{Results and Discussion}

\section{Configuration 1}

This configuration considers the $\mathrm{C}-\infty$ state in which only one fibre in the composite is broken and the constituents are considered linearly elastic, homogeneous and isotropic. The results 


\section{ACCEPTED MANUSCRIPT}

obtained for $K_{r}$ in this study are compared to those obtained by other researchers. The thickness of the composite surrounding the broken fibre is taken to be six fibre diameters. In the case of no debonding occurring at the interface, between the ends of the broken fibre and the matrix, the results obtained concur well with the results in the literature and support the validity of the approach adopted. It has been possible to determine with great precision the value of the load transfer and the values are given in Table 2.

The distribution of stress in the nearest intact fibre when there is debonding between the broken fibre and the matrix is shown in Figure 2. The results obtained are in agreement with the literature such that:

- The value of $K_{r}$ ' reduces with an increase in debonded length

- The broken fibre supports an increasing load from the point at which the interface remains intact, in an identical fashion to the case without debonding but translated along the fibre, from the break, by the length of debond

- An increase in load transfer in the region of the point at which bonding is maintained

However there is a major difference observed compared to the other models as when the debonded length is small the load transfer coefficient is superior to that when there is no debond, as shown in Figure 3. This means that models of the failure of unidirectional composites based on the concept of load transfer around broken fibres and which do not take this into account, under estimate the probability of failure. 


\section{ACCEPTED MANUSCRIPT}

\section{Configuration 2}

Encouraged by the results obtained based on the C-• cell, the periodic cells, C-2, .....C-8 and indeed C-16, representing different damage states, the influence of fibre breaks on the load transfer under these conditions has been determined, and the results are given in Table 3. The results confirm that the stress concentration due to a broken fibre is restricted to its near neighbours. The effect of debonding modifies considerably the load transfer, particularly with the increase in level of damage, shown by going from C-16 to C-2. Figure 3 shows that the development of the debonded length means that the effect of the fibre break can be transformed from being local to being a global influence on composite strength. Since the increase of the debonded length reduces its contribution to zero near the plane of the broken fibre, this results in a more homogenous load redistribution to the intact fibres remaining in this Cell.

\section{Configuration 3}

The influence on $k_{r}$ of the viscosity of the matrix has been evaluated for the different damage states considered. The matrix has been taken to be homogeneous, isotropic and its behaviour has been considered to be linearly viscoelastic. The $40 \%$ fibre volume fraction considered throughout this study has been chosen so as to clearly reveal the viscous effects of the matrix. The parameter of interest is still $k_{r}$, the load transfer to fibres neighbouring a fibre break, which in this configuration is evaluated as a function of time. Here, it is compared to the results obtained in the elastic case with the same damage states. The processes are not dissimilar in the two cases however the effect of time is seen to be important, as shown in Figure 4 as, with and without debonding, the intact fibres neighbouring a fibre break experience an increasing load concentration. 


\section{ACCEPTED MANUSCRIPT}

\section{Configuration 4}

The passage from an elastic to a plastic matrix also does not alter the fundamental mechanisms of load transfer to intact fibres neighbouring a fibre break and the study has confirmed the results of Van den Heuvel (Heuvel et al.) for different damage states in the composite. However cyclically loading the composite with a plastic matrix has the effect of locally inducing residual tensile stresses in the matrix and compressive stresses in the fibres, around the break, as shown in Figure 5. These residual stresses are created by the plastic deformation of the matrix in the vicinity of the interface with the broken fibre (Blassiau). At each cycle, the plastic deformation accumulated in the matrix around the broken fibre increases the load transfer coefficient, which, as it is accumulates with cycling, can induce further fibre failures. This damage process, which is of little significance for small strain cycles, typical experienced with first generation carbon fibre composites for which fibre failure strains were around $1 \%$ and composites were limited to $0.4 \%$ strains, could be appreciable with later generation carbon fibres with failure strains of around $2 \%$ offering increased composite strains.

\section{CONCLUSIONS}

The results of this study have allowed the loads transferred to intact fibres neighbouring a broken fibre to be evaluated with precision, as a function of the damage state of the composite and the length of debonding of the broken fibre which occurs. When the viscoelastic nature of the matrix is taken into account it has shown that the stress concentrations on intact fibres near a break increase with time and explain how elastic reinforcements, such as carbon fibres, can continue to fail in a unidirectional composite loaded in the fibre direction, even when the load on the composite remains constant. The model has confirmed that the initial effects of a 


\section{ACCEPTED MANUSCRIPT}

fibre break are localised in the composite and at a distance of several fibres from the break the stress state remains unaltered. The effect of increasing both debonding and the damage state leads to a change from the limited effects of breaks to one which affects all of the composite. In the case of an elasto-plastic behaviour of the matrix, the effects of cyclic loading can lead to a build-up of stresses on fibres neighbouring fibre breaks through the accumulation of plastic deformation in the matrix. This can add to the effects of time due to viscoelastic behaviour and result in an increase in damage in the composite, even under steady cyclic loading conditions.

\section{Acknowledgements}

The authors wish to thank the Gaz de France for its financial support for this study.

\section{References}

Cox H.L., "The elasticity and strength of paper and other fibrous materials"; British journal of applied physics, Vol. 3 (1951), 72-79.

Hedgepeth J. M. \& Van Dyke P., " Local Stress Concentrations in Imperfect Filamentary Composite Materials"; Journal of Composite Materials, Vol. 1, (1967), 294-309.

Landis C. \& McMeeking R. M., "Stress concentrations in composites with interface sliding, matrix stiffness and uneven fiber spacing using shear lag theory"; International Journal of Solids and Structures, Vol. 36 (1999), p. 4333-4361.

Nedele M.R. \& Wisnom M.R. “Three dimensional finite analysis of the stress concentration at a single fibre break"; Composites Science and Technology 51 (1994), 517-524.

Van den Heuvel, P.W.J., Goutianos S., Young R.J., Peijs T., "Failure phenomena in fibrereinforced composites. Part 6: a finite element study of stress concentrations in unidirectional carbon fibre reinforced epoxy composites"; Composites Science and Technology, Vol. 64 (2004), 645-656. 


\section{ACCEPTED MANUSCRIPT}

Blassiau S., "Etude expérimentale et numérique de la durée de vie des réservoirs sous pression en carbone/époxy", PhD thesis, Ecole Nationale Supérieure des Mines de Paris, 2005.

\section{FIGURE CAPTION}

Figure 1: Representative Elementary Volumes for the five levels of damage considered and the periodic elementary cells considered. R shows the broken fibre.

Figure 2: The stress concentration in the nearest intact fibre to the broken fibre with differing debond lengths for the elastic case in which only one fibre is broken

Figure 3: Coefficient $\mathrm{Kr}^{\prime}$ in the fibres nearest to a broken fibre as a function the debonded length at the broken fibre /matrix interface for the C-8 Cell, in the elastic case with interfacial debonding.

Figure 4: Both time and debonded length effects on the coefficients of load transfer in all intact fibres of each Cells for a viscoelastic behaviour versus the coefficient get with Elastic behaviour

Figure 5: Residual stresses in the fibres nearest to a broken fibre and in the broken fibre in function of the damage state of the composite, induced in the case of a plastic matrix. 


\section{FIGURES}

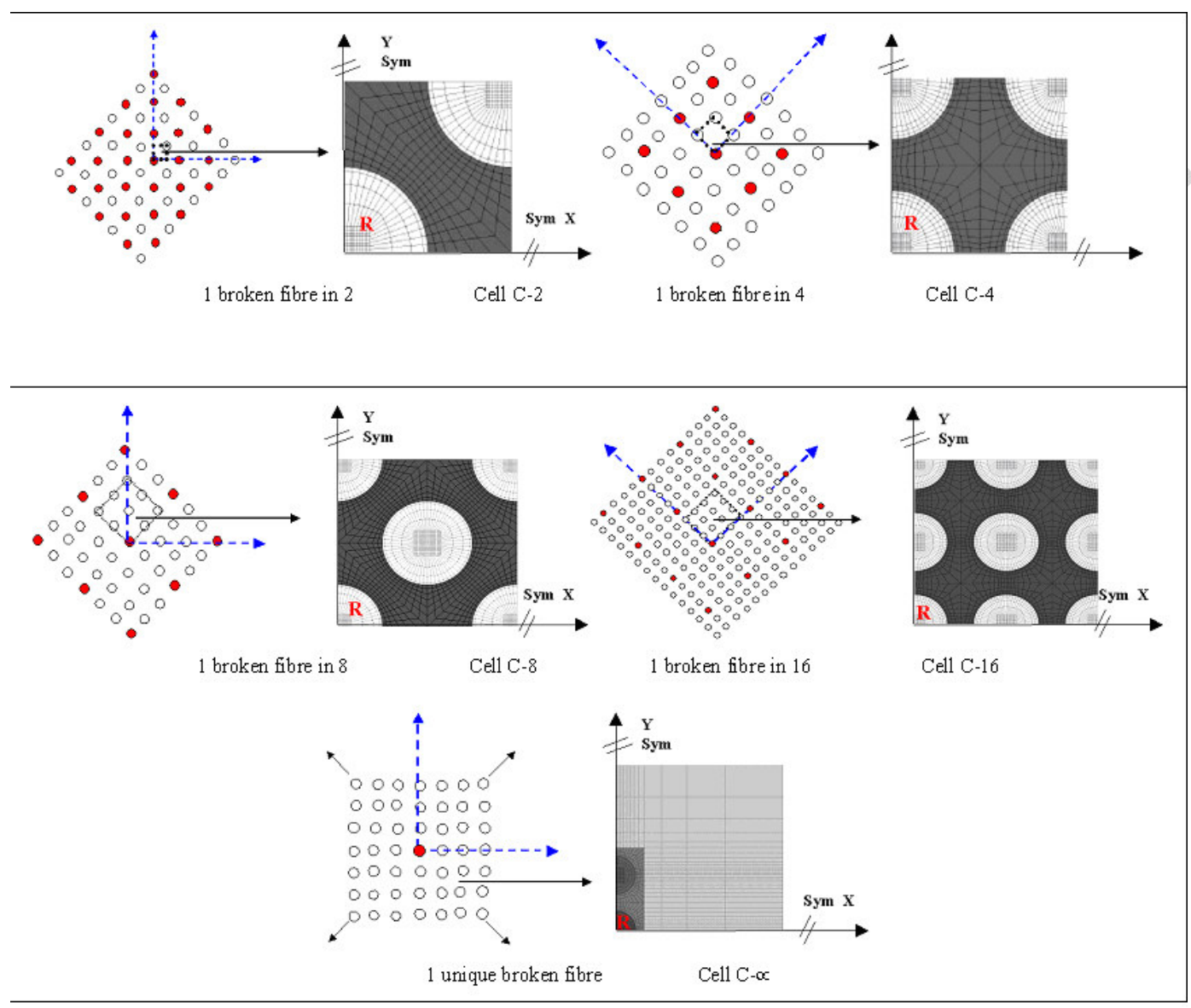

FIGURE 1 


\section{ACCEPTED MANUSCRIPT}

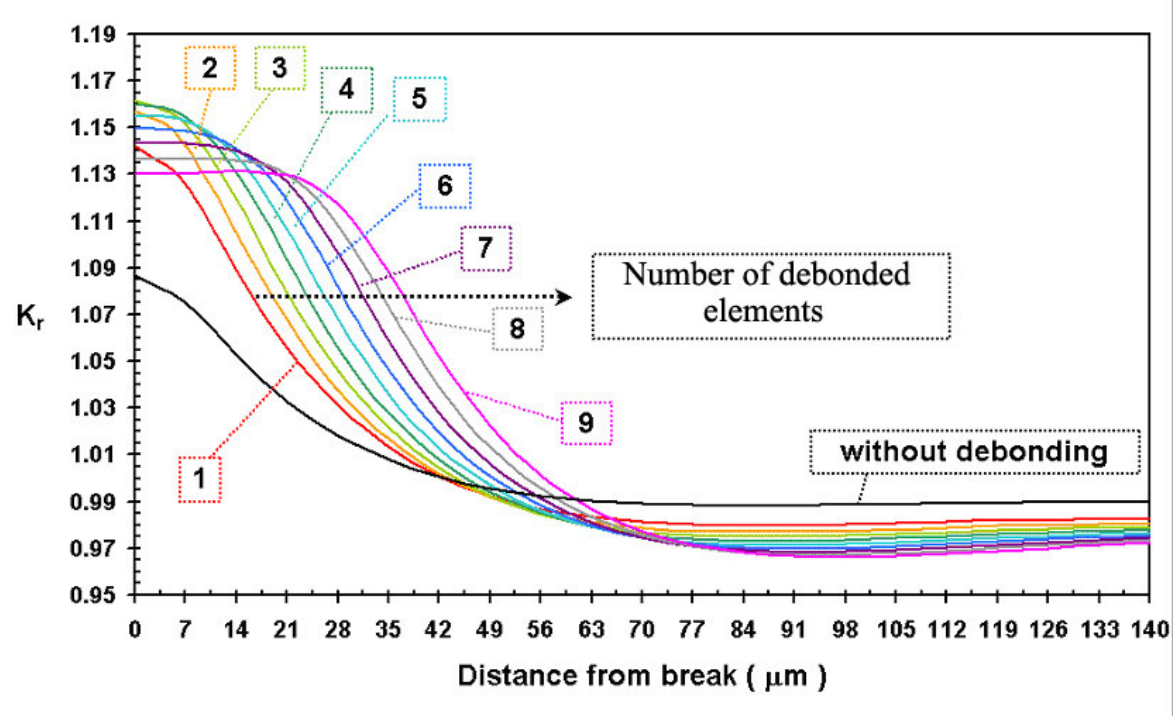

FIGURE 2

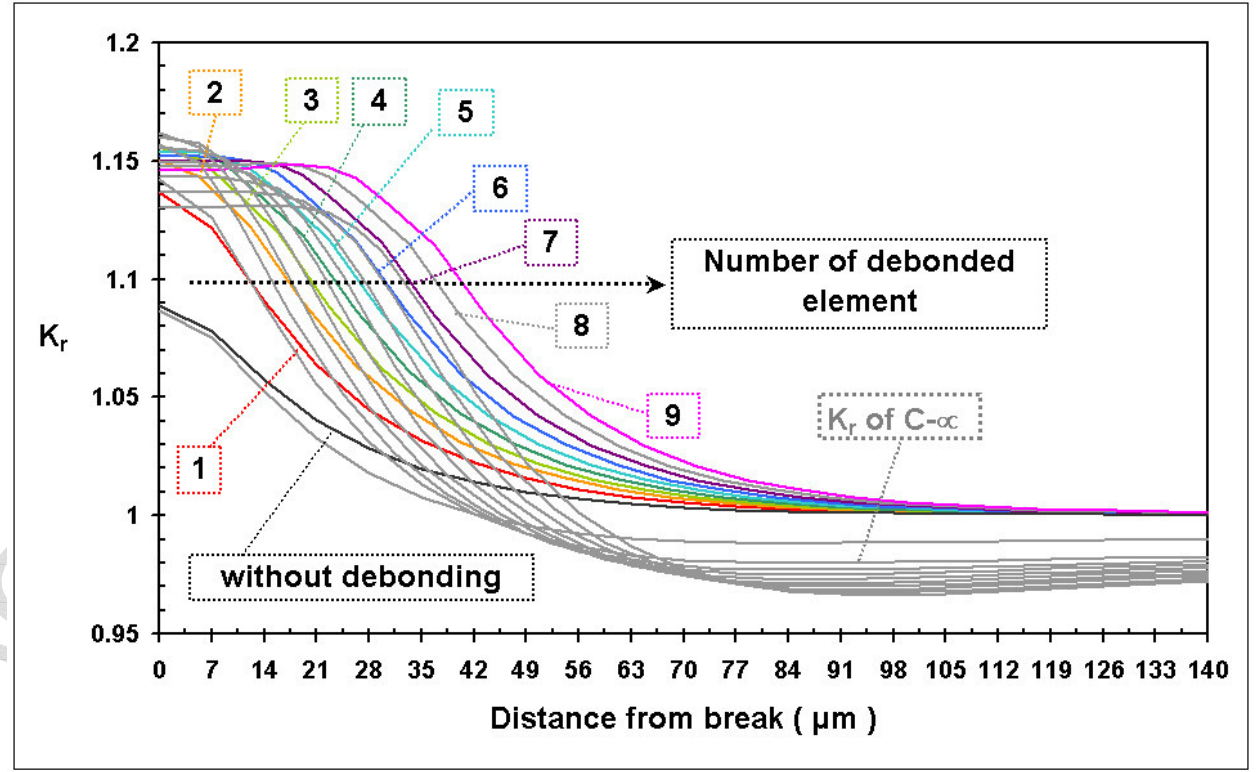

FIGURE 3 


\section{ACCEPTED MANUSCRIPT}

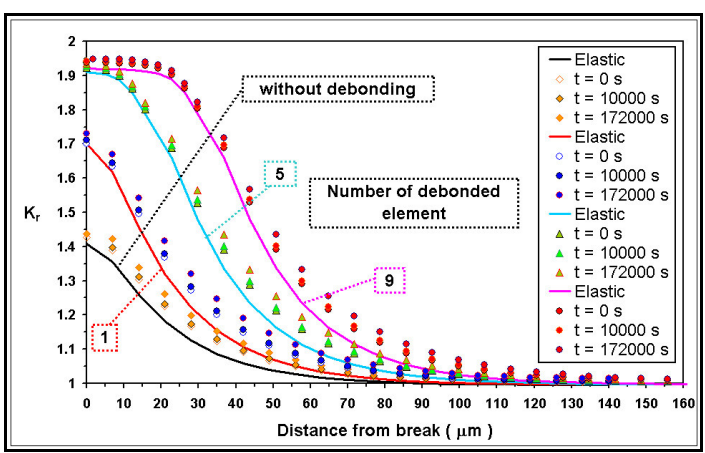

fibre 2

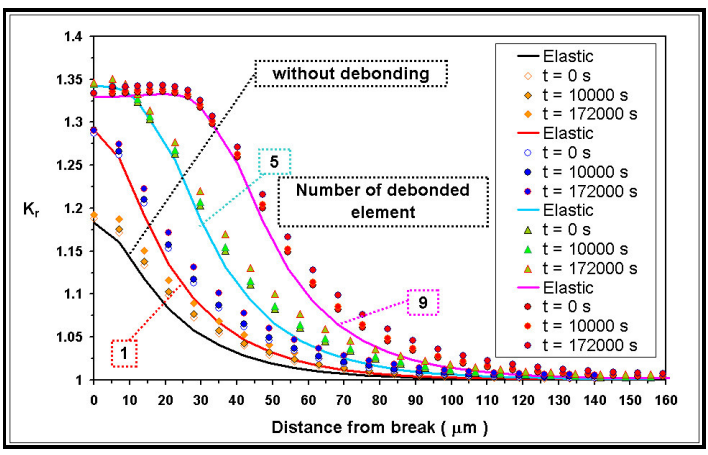

fibre 2

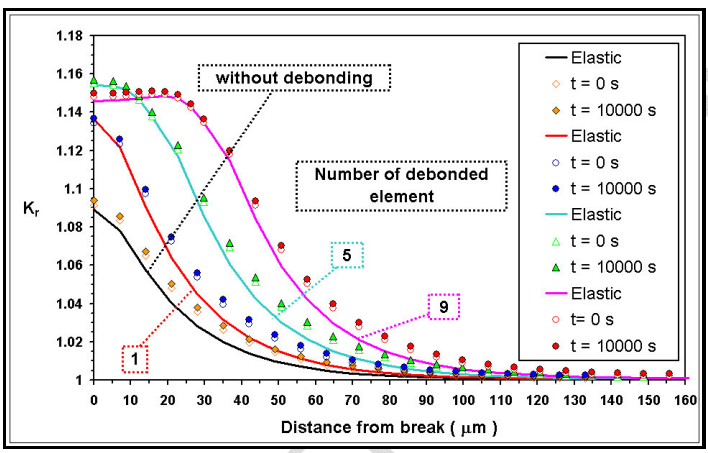

fibre 3

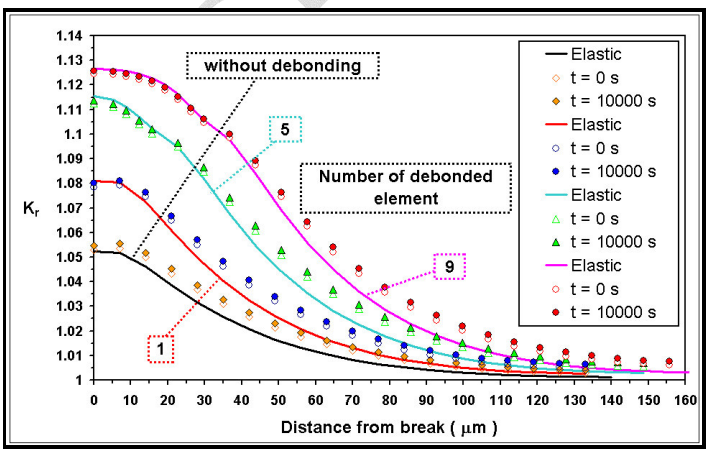

fibre 2

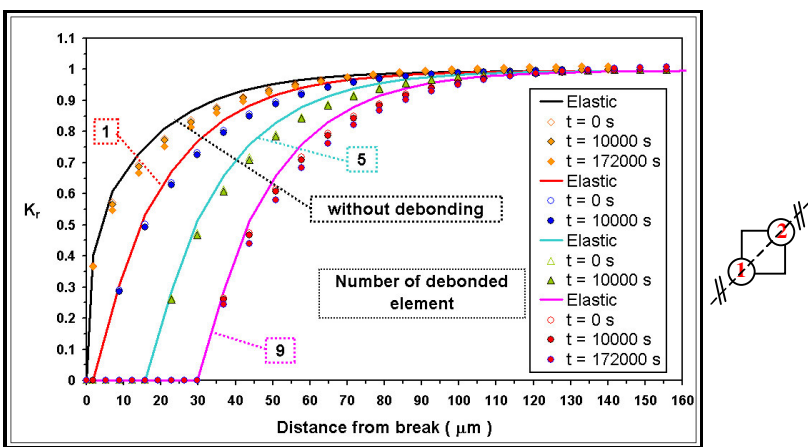

fibre 1

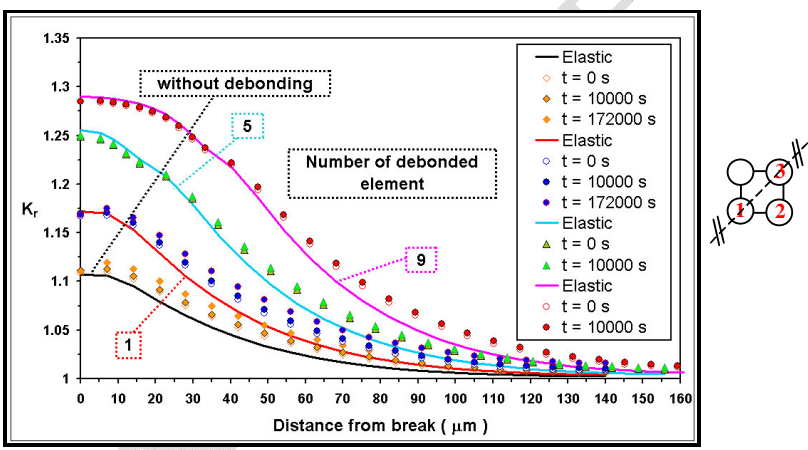

fibre 3

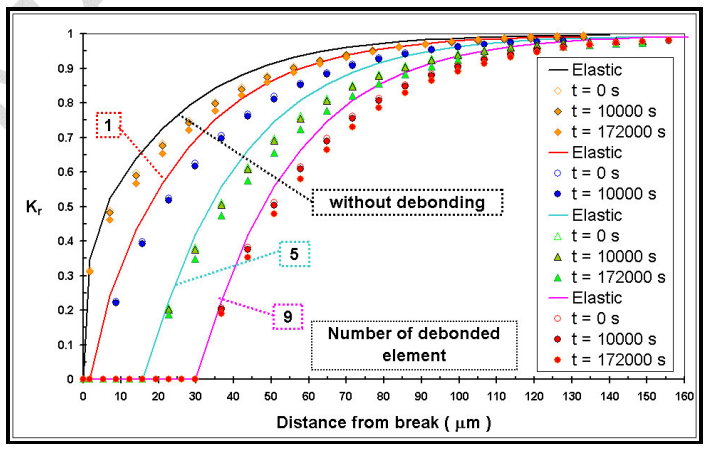

fibre 1

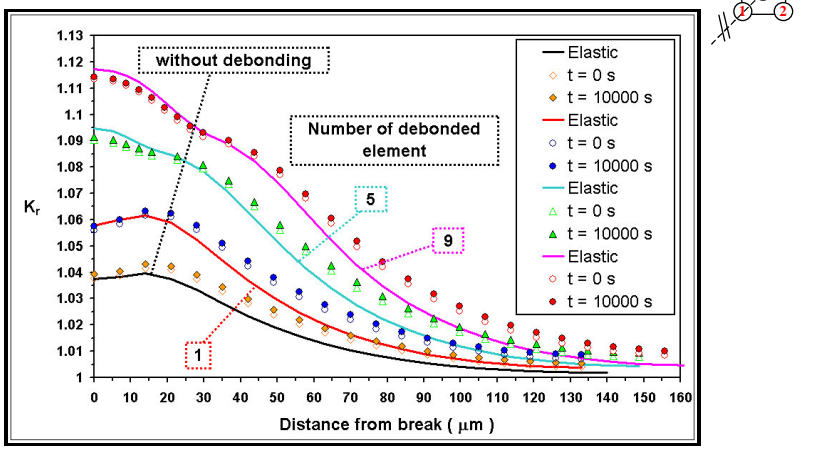

fibre 4 


\section{ACCEPTED MANUSCRIPT}
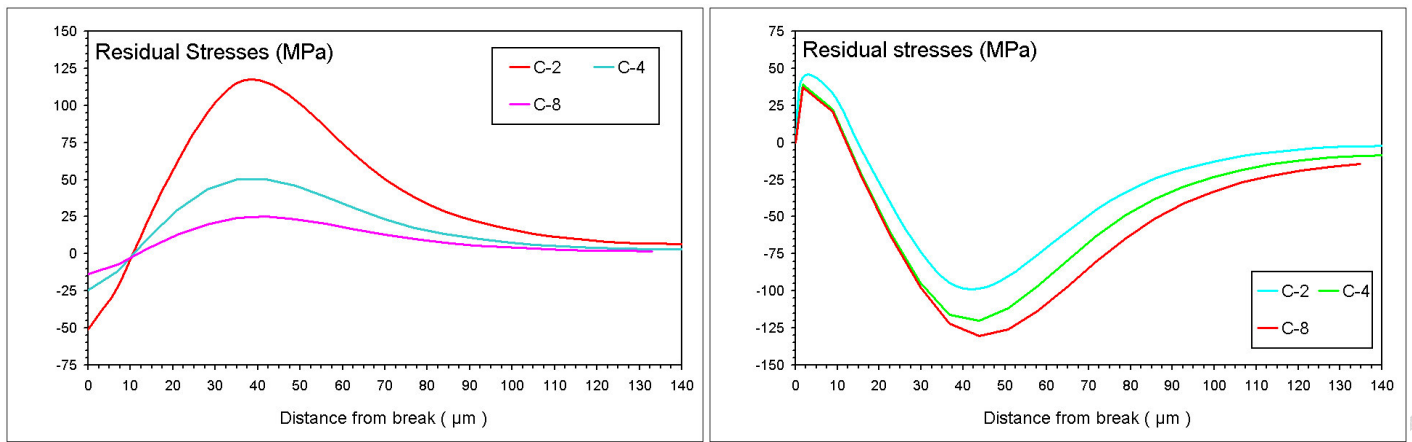

FIGURE 5

TABLE CAPTION 


\section{ACCEPTED MANUSCRIPT}

Table 1: Material parameters for the fibre and the matrix

Table 2: Coefficients $\mathrm{Kr}$, in the plane of fracture, calculated by different models for the fibres adjacent to a broken fibre, in the elastic case.

Table 3: Value of Kr coefficients in the failure plane for all cells for the elastic case showing varying degrees of damage. 


\section{ACCEPTED MANUSCRIPT}

\section{TABLE}

\begin{tabular}{|c|c|c|c|c|}
\hline Carbon fibres & \multicolumn{2}{|c|}{$E=227 \mathrm{GPa}$} & \multicolumn{2}{c|}{$v=0.30$} \\
\hline Matrx & \multicolumn{2}{|c|}{$E=3 \mathrm{GPa}$} & \multicolumn{2}{c|}{$v=0.40$} \\
\hline \multirow{2}{*}{ Composite } & $\mathrm{E}_{11}=138 \mathrm{GPa}$ & $\mathrm{E}_{22}=18.9 \mathrm{GPa}$ & $v_{12}=$ & $v_{23}=0.33$ \\
& & & 0.36 \\
\hline Matrix : short & $E_{0}=3.2 \mathrm{GPa}$ & $E_{\infty}=2.95 \mathrm{GPa}$ & $\tau=1500 \mathrm{~s}$ \\
\cline { 2 - 4 } periods of time & $v_{0}=0.40$ & $v_{\infty}=0.40$ & $v_{\tau}=-0.65$ \\
\hline Matrix : long & $E_{0}=2.85 \mathrm{GPa}$ & $E_{\infty}=2.39 \mathrm{GPa}$ & $\tau=165000 \mathrm{~s}$ \\
\cline { 2 - 4 } periods of time & $v_{0}=0.40$ & $v_{\infty}=0.40$ & $v_{\tau}=-0.65$ \\
\hline Plastic Matrix & $\mathrm{C}=2200 \mathrm{MPa}$ & \multicolumn{2}{c}{$\mathrm{R}_{0}=45 \mathrm{MPa}$} \\
\hline
\end{tabular}

TABLE 1 


\section{ACCEPTED MANUSCRIPT}

\begin{tabular}{|c|c|c|}
\hline Models & $\begin{array}{c}\text { Square distribution of } \\
\text { fibres }\end{array}$ & Hexagonal distribution of fibres \\
\hline Hedgepeth Shear-Lag 2D & 1.333 & 1.333 \\
\hline $\begin{array}{c}\text { Hedgepeth and Van Dyke } \\
\text { Shear-Lag 3D }\end{array}$ & 1.146 & 1.104 \\
\hline Nedele and Wisnom & & \\
\hline Landis & $1.081\left(\mathrm{~V}_{\mathrm{f}}=60 \%\right)$ & \\
\hline Present study & $1.075\left(\mathrm{~V}_{\mathrm{f}}=40 \%\right)$ & $1.058\left(\mathrm{~V}_{\mathrm{f}}=60 \%\right) 1.07\left(\mathrm{~V}_{\mathrm{f}}=\right.$ \\
\hline
\end{tabular}

TABLE 2 


\section{ACCEPTED MANUSCRIPT}

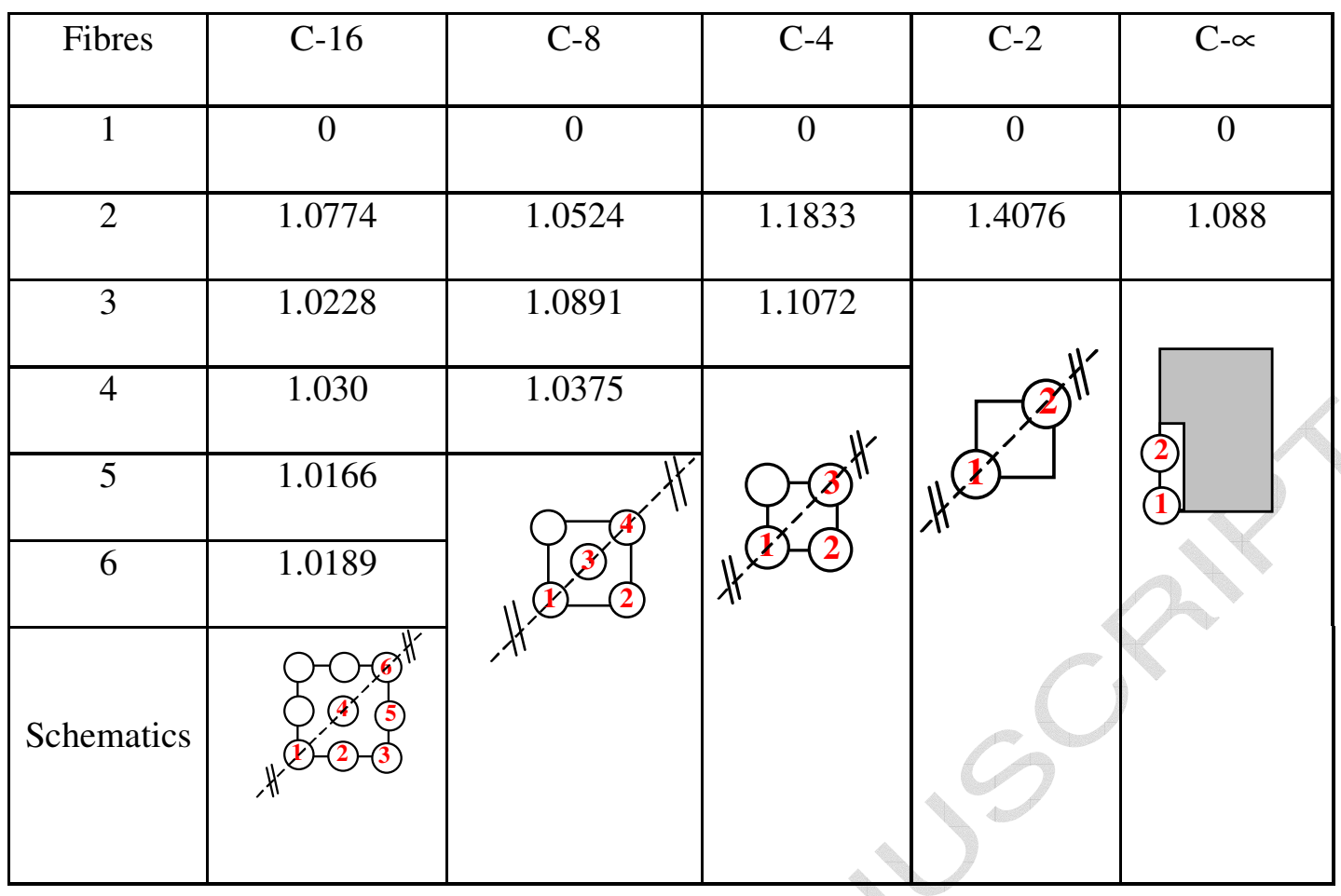

TABLE 3 